\title{
Non-performing Loans in Turkish Banking Sector and Balance Sheets Effects
}

\author{
Aylin Erdoğdu \\ Istanbul Arel University, Istanbul, Turkey
}

\begin{abstract}
In the 21 st century, while the scope of banking activities has been expanding every day, collecting deposits and providing credit remain as their main and most important functions. They transfer the collected funds thanks to the market confidence they create back to the market in terms of the credits they give. For the organizations operating in the banking sector, crediting is the highest revenue earning source. However, uncollected loans may disrupt the activities of banks and may reduce their effectiveness. Therefore, the control of bank credits has a particular importance in the bank balance sheets. In this study, the relationship between bank balance sheets and non-performing loans (NPL) will be analyzed using Granger causality test and vector autoregressive (VAR) method. This study aims to discuss the impact of NPL on balance sheets and contribute to making correct credit decisions. It also intends to assist to reduce the NPL ratios of banks and minimize the level of negativity in their financial statements.
\end{abstract}

Keywords: Turkish banking sector, non-performing loans (NPL), banks' balance sheets

\section{Introduction}

Banking is the most important sector for financial intermediation in the economic structure.

Banks collect funds from units with surplus funds and they are obliged to transfer these funds to the unit that needs funding. They carry out this task within the framework of activity, efficiency, and the opportunity costs principles. For these reasons, they are the most critical institutions of economy in terms of authority and responsibility.

One of the tools that banks use while mediating the flow of funds is lending. Banks are exposed to various risks while performing their function such as liquidity risk, interest rate risk, currency risk, operational risk, and credit risk as the most important of all.

Global economy deregulation processes in the 1980s and 1990s have been exposed to many macro-scale financial crises. In the 2000s, exceptional knowledge and rapid innovation in communication technology have led to the easy flow of the global capital from one country to another. As a result of these developments, capital is directed towards markets with the highest returns. However, as high returns can also have high risk, large consistent losses occur as a result of financial crisis. These losses are an indicator that capital sometimes diverts risky areas which are not commensurate with its return. Past crises show that the banking sector is constantly kept under mandatory supervision and control. Non-repayment of credits, inefficient financial placements, or

Aylin Erdoğdu, assistant professor, Ph.D., School of Applied Sciences, Department of Banking and Finance, Istanbul Arel University. Email: aylinerdogdu@arel.edu.tr. 
their loss of value can naturally cause banks to encounter problems when trying to fulfill their obligations. As a natural result, banks and other institutions in the system are also affected; public authorities keep the financial status of banks under constant surveillance so as not to lead to any bankruptcy. In order to achieve a more robust structure in its struggle against possible crises, the banking sector needs to be under the supervision and control of the external authorities as well as internal management mechanism. Bank analysis of customers' credit worthiness is important for credit allocation procedures prepared by its own internal system, but they need other regulations such as 5411 Banking Law and Legislation.

Credit risk is defined as the payment of loans given by the bank. The lack of an effective credit risk management leads to an increase in non-performing loans (NPL) and negatively affects the balance sheets, asset quality, profitability, and capital adequacy ratios of the banks.

Especially after the 2001 crisis in Turkey, the increase in the capital of banks led to a significant decrease in NPL, and some banks deteriorating financial structures SDIF (Savings Deposit Insurance Fund) have been transferred. Banking Regulation and Supervision Agency (BRSA) was established against these negative consequences and the Turkish banking system has gained a new structure. Learning from past experiences, the impact of NPL on the banking sector and on the economy should be kept in mind and the underlying reasons should be investigated. Albeit delayed, it should be tried to increase their collectibility through restructuring. Consequently, the cause-effect relationships should be paid attention and measures should be taken to avoid problematic loans.

The present study aims to analyze the development of NPL and NPL of the banking system in Turkey and the impact of the banks' balance sheets.

The study consists of six sections. The first section is introduction. The second section presents the relevant literature reviewed, and the methodology is given in the third section. The data sets and methods are mentioned in the fourth section, and the fifth section is devoted to the analysis of the results followed by the conclusion as the last section.

In the analysis of the monthly data on the 1986-2015-4 term, unit root analysis, Granger causality test, vector autoregressive (VAR) model, cointegration analysis, and impulse-response functions were utilized.

\section{Literature Review}

Barr, Seiford, and Siems (1994) concluded that the quality of assets is a significant statistical indicator of the bankruptcy signals. It was observed that the failed banks have too many NPLs.

By using the econometric model they established to analyze the changes in the demand for loans in banks due to the deterioration in the balance sheet, and the changes in the supply of credit by banks due to the increase in financial intermediation costs, Brunner and Kamin (1994) have reached the following conclusions:

The problems in households and business balance sheets partly explain the recession in Japan between 1991 and 1993. In addition, the fall in asset prices has been significantly effective in credits and the decrease in the economic activities. There are some findings about that the restrictions on bank loans decrease production at the beginning of the recession.

According to Asea and Blomberg (1997), asymmetric information problems causing trouble in credit markets would increase when the economy is in recession and the risk premium the banks demand from loans would rise accordingly. 
The increase in risk premiums brings in an increase in collateral demand for banks. However, the risk premium in the expansion phase of the business cycle is reduced; the loan amount will increase and decrease the possibility of guarantee. Therefore, in a high-risk environment, in order to make it difficult for risky credit customers to get loan, banks tighten their standards, and in low-risk environments, loosen their credit standards to make it easier for riskier customers to get loans. Asea and Blomberg (1997) examined the panel data set issued by 580 banks between 1977 and 1993 and based on the contractual terms of nearly 2 million commercial and investment loans, and empirically analyzed the relationship between changes in the banks' credit standards and business cycle fluctuations in total unemployment.

Keeton (1999) analyzed the increase in loan volume and the effects of debt repayment using the vector auto regression model and the data between 1982 and 1996. In the study conducted in the US, repayment of debts was defined as the failure to repay in the 90-day payment period. The resulting expansion of credit value has emerged a strong correlation between declining assets.

Domaç and Peria (2000) explored the links between exchange rate regimes and financial stability and used logit analysis to calculate the probability of a banking crisis. They stated that a decrease in trade volume can negatively affect the borrowers' debt repayment and it would increase the probability of banking crisis.

Using panel data models in several sub-Saharan countries, Fofack (2005) revealed the existence of a relationship between the variables such as the economic growth, the real exchange rate increases, real interest rates, net interest earnings, and the debt that cannot be repaid in cash. Podpiera and Weill (2008) examined the relationship between cost-effectiveness and NPL of the banking sector in the Czech Republic for the period of 1994-2005. They provided strong evidence for the favor of mismanagement hypothesis and have claimed the need for the regulatory authorities in developing countries to focus on managerial performance in order to increase the stability of the financial system by reducing NPLs.

A. Çifter, Yilmazer, and E. Çifter (2009) conducted a study for June 2001-November 2007 period using the neural network method based on decomposition and stated that the industrial production has identified a delayed effect on the amount of NPL in the Turkish financial system.

Gilchrist and Zakrajsek (2011) have investigated the relationship between credit supply and bank lending conditions in the US economy in the data period of January 1952-April 2010 using VAR analysis data. The variables of the study are unemployment rate, industrial production index, inflation, bond premiums, consumer loans, business loans, a ten-year nominal treasury income, and nominal federal interest rate. Disruptions in the financial markets are measured by the increase in bond premium. It was found that the first reaction of banks to the financial problems in the financial markets is the rejection of loan applications and the reduction of credit amount in their balance sheets. Cyclical decline in business loans after a certain delay emerges as a key feature of the fluctuation.

Mimir (2013) examined the 1987-2010 period for the US banking sector, bank loans, deposits, financial variables, such as the conjuncture of the net value of properties. One of the main findings obtained through the theoretical models is that financial shocks affect not only financial variables but also the macro variables. The shocks in the net worth of the banks affect the adequacy of bank lending. Another important result obtained in the present study is that the conjuncture of bank credit is a leading variable and causes production fluctuations from a quarter to three-quarter term.

Studies on NPL in Turkey focus rather on macroeconomic activities. They handle the issue from the perspective of financial sophistication. 
The present study analyzes the relationship between bank loans and balance sheet asset quality, and associates bank loans with the variables consisting balance sheet items. The following section analyzes the 1986-2015/4 period in Turkey by dividing it into sub-periods.

\section{Scope of NPL}

\section{Definition of NPL}

NPL, due to deterioration of the repayment agreement between the bank and the debtor company and the emergence of the damage, is likely to delay the collection (Aktaş, 2000).

To define the NPL and promote the application of the standard, a regulation was issued on November 1, 2006 by the BRSA in Turkey. Aforementioned regulation name is: "Regulation on the Procedures and Principles for Determination of Qualifications of Loans and Other Receivables by Banks and Provisions to be Set Aside" (Official Gazette of the Republic of Turkey, 2006).

According to this regulation:

For which recovery of principal and interest or both delays for more than 90 days from their terms;

Loans and other receivables with limited recovery means: This group includes the loans and other receivables, for which the delay of recovery of principal or interest or both from respective terms or due dates exceeds 180 days from their terms;

Loans and other receivables with suspicious recovery: This group includes the loans and other receivables;

For which it is believed by banks that such loans and receivables have suffered weakness and that debtors have totally lost their credit worthiness since it is quite likely that non-performance of entire recovery of any sums falling due or becoming payable in a period of longer than one year;

Loans and other receivables having the nature of loss: This group includes classification of loans and other receivables are regarded.

\section{Assessment of the Problem Loans}

As of April 2015, a total of 51 banks were operating in the Turkish banking sector:

(1) 34 deposit banks;

(2) 13 investment and development banks;

(3) Four participation banks.

In this study, we used the aggregated balance sheets of deposit money, investment and development, and participation banks.

The chronic inflation after 1980 and the rise in the exchange rates and interest rates increased credit costs. NPL has emerged as a natural consequence of this process.

BRSA has struggled for many years with the liquidation proceedings a few private banks which went bankrupt after the 2001 crisis and confiscated by the Saving Deposit Insurance Fund (SDIF), and the NPL of the state-owned banks and private banks.

According to the values (see Table 1), in the last 5.25 years, the increase in NPL is more than the increase in credit volume. The aim of protecting the profitability of rapidly evolving economic dynamics and an increasingly competitive environment has led banks to work with aggressive policies. Flexible credit valuation stems from this aggression. 
Table 1

The Turkish Banking Sector Credit Volume (Thousand TL)

\begin{tabular}{|c|c|c|c|c|c|c|}
\hline Year & 2010 & 2011 & 2012 & 2013 & 2014 & $2015 / 4$ \\
\hline Total loans & $4,879,118,630$ & $6,880,738,903$ & $8,382,858,519$ & $10,700,934,205$ & $13,294,418,399$ & $5,107,136,881$ \\
\hline NPL (Net) & $41,037,582$ & $38,338,833$ & $56,669,803$ & $78,040,492$ & $99,298,773$ & $40,427,943$ \\
\hline $\begin{array}{l}\text { Special reserves } \\
\text { for loans }(-)\end{array}$ & $210,238,478$ & $185,779,451$ & $194,375,069$ & $240,661,222$ & $296,730,003$ & $111,937,737$ \\
\hline
\end{tabular}

Note. Source: Central Bank of the Republic of Turkey (CBRT, 2015).

Since the second half of 2013 , due to the uncertainty created by the global macro-financial factors depending on the fluctuations in the risks and the domestic market, there has been an increase in the risk premium indicators, interest rates, and the depreciation of the Turkish Lira.

That period was followed by a cautious monetary policy by the Central Bank and the upper limit of the interest rate corridor has been raised. As a result of the constant rise in exchange rates, foreign exchange liquidity is provided by concentrating on the foreign exchange selling auctions.

The adverse market conditions have continued in 2014 with the global uncertainty and the maintaining rising trend of interest rates. Tightening monetary policy has continued and emphasis was given to the transfer of funds to the market with a one-week repo auctions.

The market share of a bank has a direct impact on risk perception. In a competitive environment, the cost of missed opportunities in the market determines the bank's place in the sector. Therefore, it should determine the optimal risk scale in the allocation of bank credit.

The high risks taken due to keen competitive conditions may turn into NPL for the bank. This causes a high cost for banks.

NPL causes:

(1) The deterioration of asset quality in the bank's balance sheet;

(2) Reduction of liquidity;

(3) Specific reserves for loans;

(4) Negative impact on profitability and capital;

(5) The reduction of branch profitability;

(6) The deterioration of asset-liability management.

Table 2

Asset Quality Change in the Turkish Banking Sector

\begin{tabular}{lccccrr}
\hline Year & $2010(\%)$ & $2011(\%)$ & $2012(\%)$ & $2013(\%)$ & $2014(\%)$ & $2015 / 4(\%)$ \\
\hline Total loans/total assets & 48 & 53 & 57 & 60 & 62 & 63 \\
NPL (Brut)/total loans & 5,150 & 3,257 & 2,995 & 2,978 & 2,979 & 2,983 \\
Special reserves for loans/NPL (Brut) & 84 & 83 & 77 & 76 & 75 & 73 \\
\hline
\end{tabular}

Note. Source: CBRT (2015).

As Table 2 shows, total loans to total assets ratio has increased. In the last three years, the ratio of NPL to total loans remained at the same level. Decrease acceleration has been identified in the ratio of specific provisions for NPL.

As Table 3 shows, the net profit to total assets ratio and the profit reserves to total assets ratio have decreased in the last three years. Increased competition and conjunctural fluctuations support this momentum. 
Table 3

Profitability Changes in the Turkish Banking Sector

\begin{tabular}{lllllll}
\hline Year & $2010(\%)$ & $2011(\%)$ & $2012(\%)$ & $2013(\%)$ & $2014(\%)$ & $2015 / 4(\%)$ \\
\hline Net profit/total asset & 1.47 & 0.94 & 1.02 & 0.92 & 0.69 & 0.25 \\
Profit reserves/total asset & 6.84 & 6.94 & 7.31 & 7.25 & 7.09 & 6.75 \\
\hline
\end{tabular}

Note. Source: CBRT (2015).

\section{Methodology}

The study evaluates the consolidated data (monthly, thousand TL) on the aggregated balance sheets of the deposit money, investment and development, and participation banks.

The relationship between NPL and selected balance sheet items (total loans, NPL, special reserves for loans, profit/loss, and profit reserves) was analyzed using the 1986-2015/4 monthly data.

The data on the selected variables were collectively announced in 1986. The latest data are for April 2015; therefore, 1986-2015 study/4th semester is selected.

The time series data used in the study have been compiled from CBRT, the Electronic Data Dissemination System and the BRSA website. Analysis is made using E-views 8 program.

This study uses monthly real growth rate of past-due loans as an indicator of NPL, real growth rate of domestic credit volume as an indicator of credit (CRE), real growth rate of special reserves for loans as an indicator of provision (PRVS), real growth rate of profit/loss as an indicator of profit (PRF), and real growth rate of profit reserves as an indicator of reserves (RSRV).

The econometric analysis was performed for all variables entering the regression, determination, and elimination of seasonal adjustment, increasing the reliability of the coefficient. Monthly data were used in the study. Seasonally analysis was conducted. Profit/loss (PRF) variable is seasonality adjustment. The seasonal effect of the purification "moving average" method is used.

Cointegration is a statistical property related to the series of degrees of stability and integration. The stationary series with a fixed average value does not change throughout the sample period. For instance, the average of a series of subsets of the same series is not significantly different from the average of another subset. The first difference of the series should be taken to obtain stationary series. The resulting series will be co-integrated at the first degree.

In econometrics, cointegration analysis is used to estimate and test stationary linear relations, or cointegration relations among non-stationary time series variables such as consumption and income, interest rates at different maturities, and stock prices. The VAR model framework has been widely applied to model cointegration system. The most important decision in the modeling of cointegrated systems is the determination of the number of cointegrating relations or the cointegration rank. Cointegration exists between two or more non-stationary time series if they have the same order of integration, and a linear combination (weighted average) of these series is stationary (Paul, 2013).

VAR models were introduced by Sims (1980) as a combination of simultaneous equations time series with univariate time series models.

AVAR model can be written as follows:

$$
y_{t}=a_{1}+\sum_{i=1}^{P} b_{1 i} y_{t-i}+\sum_{i=1}^{P} b_{2 i} x_{t-i}+v_{1 t}
$$




$$
x_{t}=c_{1}+\sum_{i=1}^{P} d_{1 i} y_{t-i}+\sum_{i=1}^{P} d_{2 i} x_{t-i}+v_{2 t}
$$

It has become a prevalent method of time-series modeling. VAR model makes comments for the future. One-unit increase in one of the faults of the VAR model in the impulse-response analysis shows the response of a variable regarding its current and future values. Estimated impact-response gives information about the permanence of change against shocks.

\section{Findings}

In the study, Augmented Dickey Fuller (ADF) statistics are used for testing stationarity of the series. According to the results given in Table 4, the series used in the study are found to be stable at the $5 \%$ significance level and original level. Series are made stationary by taking their first differences.

Table 4

Unit Root Test Results

\begin{tabular}{ll}
\hline Unit root test results & ADF test \\
(1st difference, Exogenios: None) & $t$-value \\
\hline Variable & -12.19098 \\
$C R E$ & -8.449246 \\
$N P L$ & -5.391254 \\
$P R F$ & -2.016942 \\
$P R V S$ & -16.60557 \\
$R S R V$ & \\
\hline
\end{tabular}

It is necessary to determine the level of lag order for cointegrated analysis.

As shown in Table 5, results suggest 3 lag orders. Results also reveal that the appropriate model is VAR 3.

Table 5

VAR Lag Order Selection Criteria

\begin{tabular}{lllllll}
\hline Lag & LogL & LR & FPE & AIC & SC & HQ \\
\hline 0 & $2,746.639$ & NA & $7.85 \mathrm{e}-14$ & -15.98623 & $-15.93029^{*}$ & $-15.96395^{*}$ \\
1 & $2,760.975$ & 28.17081 & $8.35 \mathrm{e}-14$ & -15.92405 & -15.58839 & -15.79035 \\
2 & $2,793.377$ & 62.72668 & $8.00 \mathrm{e}-14$ & -15.96721 & -15.35183 & -15.72209 \\
3 & $2,870.148$ & 146.3790 & $5.92 \mathrm{e}-14^{*}$ & $-16.26908^{*}$ & -15.37399 & -15.91254 \\
4 & $2,884.143$ & 26.27603 & $6.31 \mathrm{e}-14$ & -16.20491 & -15.03010 & -15.73695 \\
5 & $2,898.584$ & 26.69367 & $6.72 \mathrm{e}-14$ & -16.14335 & -14.68881 & -15.56396 \\
6 & $2,942.413$ & 79.73598 & $6.03 \mathrm{e}-14$ & -16.25314 & -14.51889 & -15.56233 \\
\hline
\end{tabular}

Notes." indicates lag order selected by the criterion. LR: Sequential modified LR test statistic (each test at 5\% level). FPE: Final prediction error; AIC: Akaike information criterion; SC: Schwarz information criterion; HQ: Hannan-Quinn information criterion.

Johansen co-integration test is performed in Table 6. According to test results, there is a co-integration relationship between the series. Therefore, there is a long-term relationship among the variables.

Causality analysis is made to determine the direction of the relationship between long-term series. The results of this analysis are shown in Table 7.

According to the results in the table, there is a one-way relationship between NPL and the volume of domestic credit and among special provisions, profits, and profit reserves. 
Table 6

Johansen Cointegration Test Results

\begin{tabular}{|c|c|c|c|c|}
\hline \multicolumn{5}{|c|}{ Unrestricted cointegration rank test (Trace) } \\
\hline Hypothesized no. of CE (s) & Eigenvalue & Trace statistic & 0.05 critical value & Prob. $^{* *}$ \\
\hline None $^{*}$ & 0.317590 & 425.9002 & 79.34145 & 0.0001 \\
\hline At most $1^{*}$ & 0.303512 & 293.3030 & 55.24578 & 0.0001 \\
\hline At most $2^{*}$ & 0.205567 & 167.7917 & 35.01090 & 0.0000 \\
\hline At most $3^{*}$ & 0.134596 & 87.93759 & 18.39771 & 0.0001 \\
\hline At most $4^{*}$ & 0.103147 & 37.77565 & 3.841466 & 0.0000 \\
\hline \multicolumn{5}{|c|}{ Unrestricted cointegration rank test (Maximum Eigenvalue) } \\
\hline Hypothesized no. of CE (s) & Eigenvalue & Max-Eigen statistic & 0.05 critical value & Prob. $^{* *}$ \\
\hline None $^{*}$ & 0.317590 & 132.5972 & 37.16359 & 0.0000 \\
\hline At most $1^{*}$ & 0.303512 & 125.5113 & 30.81507 & 0.0000 \\
\hline At most $2^{*}$ & 0.205567 & 79.85408 & 24.25202 & 0.0000 \\
\hline At most $3^{*}$ & 0.134596 & 50.16194 & 17.14769 & 0.0000 \\
\hline At most $4^{*}$ & 0.103147 & 37.77565 & 3.841466 & 0.0000 \\
\hline
\end{tabular}

Notes. Trace test indicates 5 cointegrating eqn(s) at the 0.05 level. Max-eigenvalue test indicates 5 cointegrating eqn(s) at the 0.05 level. ${ }^{*}$ denotes rejection of the hypothesis at the 0.05 level; ${ }^{* *}$ MacKinnon-Haug-Michelis (1999) $p$-values.

Table 7

Granger Causality Test Results

\begin{tabular}{ll}
\hline Hypothesis & Prob. \\
\hline CRE does not Granger cause NPL & 0.0931 \\
CRE does not Granger cause PRF & 0.8570 \\
CRE does not Granger cause PRVS & 0.3637 \\
CRE does not Granger cause RSRV & 0.1730 \\
NPL does not Granger cause CRE & 0.0000 \\
NPL does not Granger cause PRF & 0.3341 \\
NPL does not Granger cause PRVS & 0.0570 \\
NPL does not Granger cause RSRV & 0.1519 \\
PRF does not Granger cause CRE & 0.1196 \\
PRF does not Granger cause NPL & 0.3861 \\
PRF does not Granger cause PRVS & 0.6981 \\
PRF does not Granger cause RSRV & 0.7882 \\
PRVS does not Granger cause CRE & 0.8022 \\
PRVS does not Granger cause NPL & 0.1102 \\
PRVS does not Granger cause PRF & 0.9837 \\
PRVS does not Granger cause RSRV & 0.2262 \\
RSRV does not Granger cause CRE & 0.3471 \\
RSRV does not Granger cause NPL & 0.0286 \\
RSRV does not Granger cause PRF & 0.0409 \\
RSRV does not Granger cause PRVS & 0.0000
\end{tabular}

Figures 1 and 2 are shown in the table below. No two-way relationship is observed among the variables.

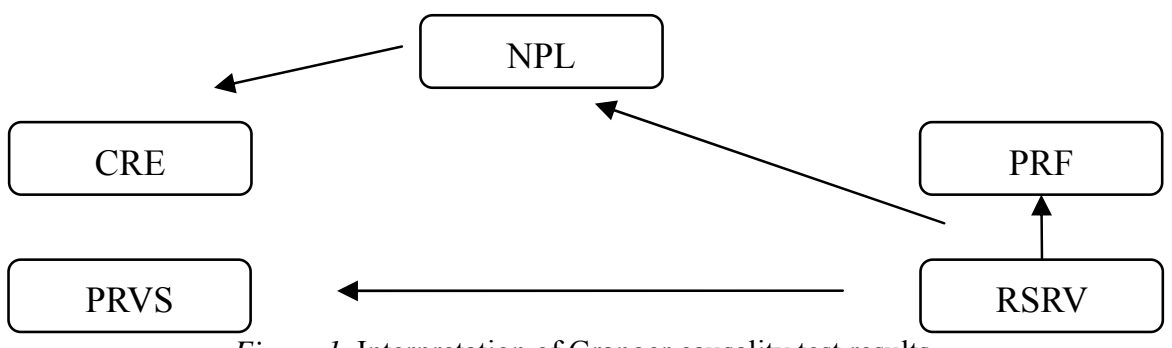

Figure 1. Interpretation of Granger causality test results. 
Responseto Cholesky One S.D. Innovations \pm 2 S.E.
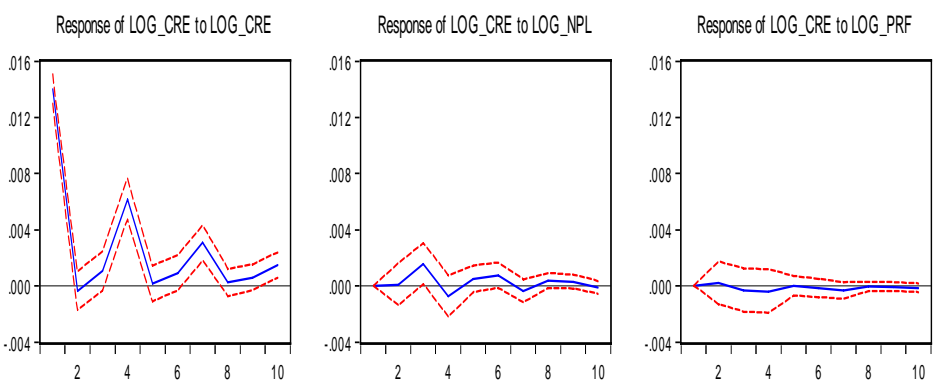

Response of LOG_CRE to LOG_PRVS

Response of LOG_CRE to LOG_RSRV
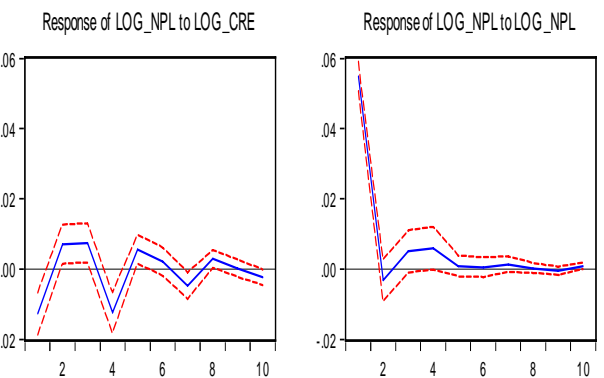

Response of LOG_NPL to LOG PRF
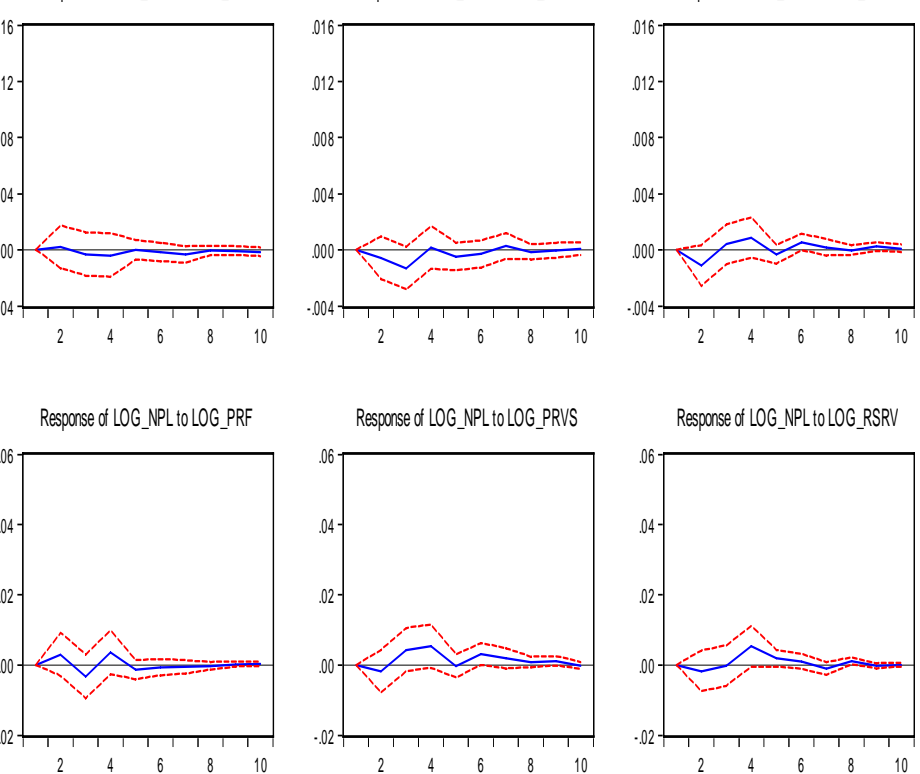

Response of LOG NPL to LOG PRVS

Response of LOG NPL to LOG RSRV
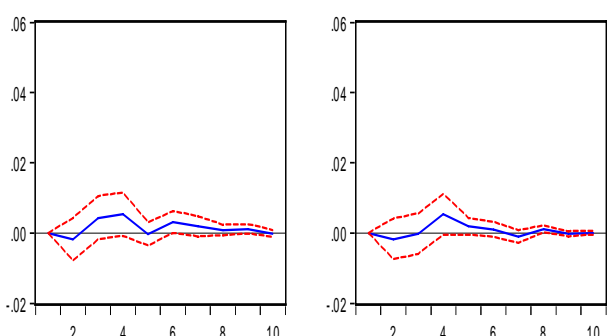

Response of LOG_PRF to LOG_CRE

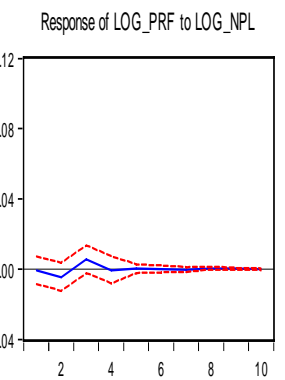

Response of LOG_PRF to LOG_PRF

Response of LOG_PRF to LOG_PRVS

Response of LOG_PRF to LOG_RSRV
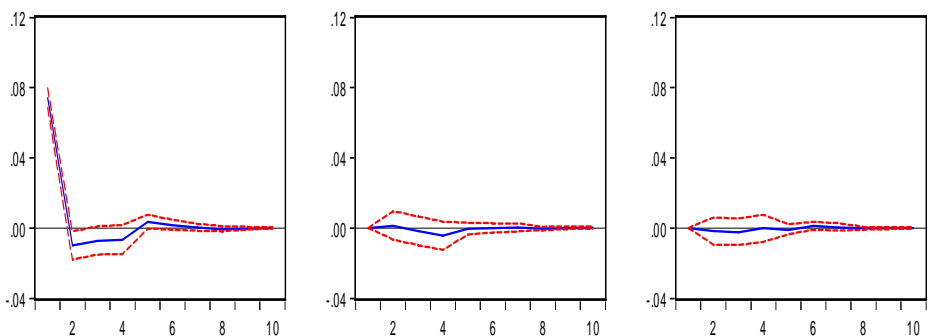

Response of LOG_PRVS to LOG_CRE
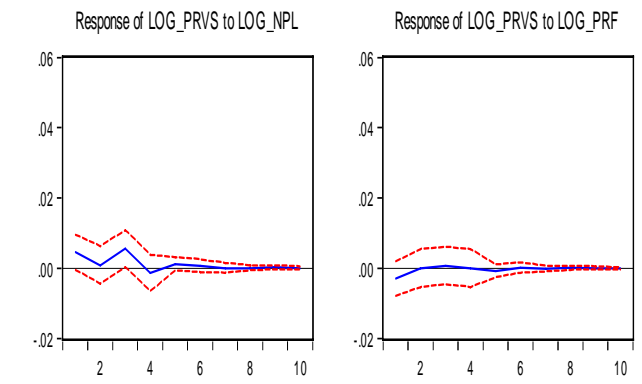

Response of LOG_PRVS to LOG_PRVS

Response of LOG_PRVS to LOG_RSRV
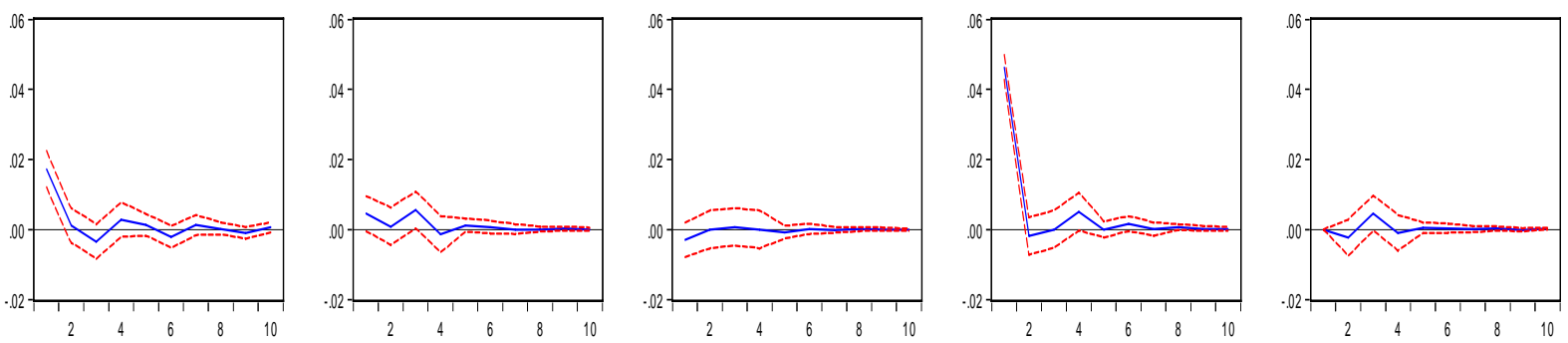

Response of LOG RSRV to LOG CRE

Response of LOG RSRV to LOG NPL

Response of LOG RSRV to LOG PRF

Response of LOG RSRV to LOG PRVS

Response of LOG_RSRV to LOG_RSRV
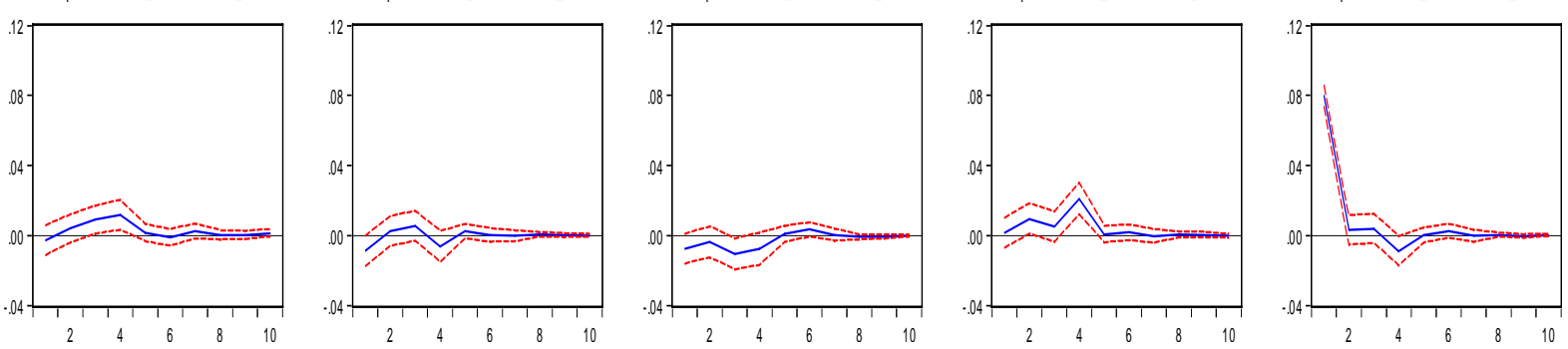

Figure 2. Impulse-response graphics. 


\section{Conclusion}

In recent years, private banking approach is widespread. Banks giving personalized service specialize in niche areas, and competitiveness has come to the fore. Since 2005, banks have concentrated on sustainable growth, and to achieve this goal, they focused on geographic spread, operational convenience, customer orientation, and acquisition and alliances.

According to the survey results, the effectivity of lending activities, which are the most important source of income, greatly affects the performance of banks and the overall economic stability.

The share of NPL in total credit is steadily increasing and they have a negative impact on the banking sector.

Provisions for NPL negatively affect banks' balance sheets, the deterioration of the loan portfolio quality and lead to a decline in the net asset profitability of banks. NPL policy of the bank has been limited by law.

If NPL cannot be charged, provision is made according to "Regulation on the Procedures and Principles for Determination of Qualifications of Loans and Other Receivables by Banks and Provisions to be Set Aside". NPL indicates asset quality of the financial sector in the economy, the capacity of households, and the real sector to pay the debt. Therefore, loans are important risk indicators that need to be managed and monitored precisely. Having fewer NPL refers to the success of a bank's risk management. Banks should be interested in preventing loans from turning into NPL rather than dealing with the management of NPL. To achieve this, banks should have effective risk management systems. Credit risk management necessitates the development and implementation of the required processes for the identification, evaluation, observation, and measurement of the possible risks that may arise as a result of lending activities.

\section{References}

Aktaş, R. (2000). Sorunlu Krediler. TBB, Basılmamış Seminer Notları, Ankara.

Asea, P. K., \& Blomberg, S. B. (1997). Lending cycles. NBER Working Paper, No. 5951.

Barr, R. S., Seiford, L. M., \& Siems, T. F. (1994). Forecasting banking failure: A non-parametric frontier estimation approach. Recherches Économiques de Louvain/Louvain Economic Review, 60(4), 417-429.

Brunner, A. D., \& Kamin, S. B. (1994). Determinants of the 1991-93 Japanese recession: Evidence from a structural model of the Japanese economy. International Finance Discussion Papers No. 479, Board of Governors of the Federal Reserve, Washington, D.C..

Central Bank of the Republic of Turkey [CBRT]. (2015). Retrieved from http://www.tcmb.gov.tr/

Çifter, A., Yilmazer, S., \& Çifter, E. (2009). Analysis of sectoral credit default cycle dependency with wavelet networks: Evidence from Turkey. Economic Modelling, 26(6), 1382-1388.

Domaç, G., \& Peria, S. M. (2000). Banking crises and exchange rate regimes: Is there a link? World Bank.

Fofack, H. L. (2005). Non-performing loans in sub-Saharan Africa: Causal analysis and macroeconomic implications. World Bank Policy Research Working Paper No. 3769.

Gilchrist, S., \& Zakrajsek, E. (2011). Bank lending and credit supply shocks. NBER Working Paper, No: 14863.

Keeton, W. R. (1999). Does faster loan growth lead to higher loan losses? Federal Reserve Bank of Kansas Economic Review, 84(2), 57-75.

Mimir, Y. (2013). Financial intermediaries, credit shocks and business cycles. TCMB Working Paper, No: 13/13, 1-77.

Official Gazette of the Republic of Turkey. (2006). Regulation on the procedures and principles for determination of qualifications of loans and other receivables by banks and provisions to be set aside (Vol. 26333).

Paul, K. R. (2013). Cointegration. In B. Gurung, \& A. K. Paul (Eds.), Recent Advances in Statistical Modelling Techniques içinde (pp. 281-288). New Delhi.

Podpiera, J., \& Weill, L. (2008). Bad luck or bad management? Emerging banking market experience. Journal of Financial Stability, 4(2), 135-148.

Sims, C. A. (1980). Macroeconomics and reality. Econometrica, 48(1), 1-48. 